\title{
Mean Performance and Heterosis for Yield and Fruit Traits of Tomato under Drought Conditions
}

\author{
Lotfy A. A. Badr; M. M. El Nagar and S. M. Yahia \\ Horticulture Dept., Faculty of Agriculture, Benha University, Benha, Egypt. \\ Correspondence author: safiya.my@gmail.com
}

\begin{abstract}
The present study was carried out in a private farm, Kaha city, Kalyobiya Governorate, Egypt during summer seasons of 2015 and 2016 to study the mean performance and heterosis for yield and fruit traits for six tomato cultivars, i.e. Tan Shit Star $\left(\mathrm{p}_{1}\right)$, Real Stone $\left(\mathrm{p}_{2}\right)$, Pearsone Imp $\left(\mathrm{p}_{3}\right)$, Super marmande $\left(\mathrm{p}_{4}\right)$, grown under normal irrigation and drought stress. This investigation was a half diallel $\mathrm{F}_{1}$ cross experiment to induce genetic variability by hybridization and evaluation and selection for best genotypes of tomato compared with the parents under drought conditions and normal irrigation. Two adjacent experiments were conducted. Where, the first experiment was irrigated every month (environment 1 ) and the second one was normally irrigated, i.e., every 2 week (environment 2). The data of the two experiments were subjected to proper statistical analysis of variance and estimate the mean performance of parents and their crosses. Data indicated that the $\mathrm{P}_{6}$ gave the highest values for total yield per plant under drought stress and combined analysis, respectively while the cross $\mathrm{P}_{1} \mathrm{XP}_{4}$ and $\mathrm{P}_{1} \mathrm{xP}_{6}$ expressed the highest values for total yield per plant under drought stress, normal irrigation and combined analysis. Moreover the highest number of fruits was detected for the parent $\mathrm{P}_{5}$ and the cross $\mathrm{P}_{5} \mathrm{xP}_{6}$ in drought condition, normal irrigation and combined analysis. Three, three and two crosses expressed significant or highly significant and positive heterosis relative to mid parent for fruits number in drought condition, normal irrigation and combined analysis, respectively. Moreover, highly significant and positive better parent heterosis were detected in 3, 2 and 2 crosses in drought stress, normal irrigation and combined analysis, respectively. It was clear that the cross $\mathrm{P}_{1} \times \mathrm{P}_{4}$ expressed the highest desirable heterosis relative to mid parent and better parent in the two environments treatments and combined analysis of them.
\end{abstract}

Key words: Heterosis, Yield, Tomato, Drought.

\section{Introduction}

Tomato (Lycopersicon esculentum Mill.) is the most popular and widely grown vegetables in Egypt. The cultivated area estimated by 468510 fed. with an average yield of 16.493 tons per fed. (Ministry of Agriculture and Land Reclamation A. R. Egypt, 2015). The hybrid cultivars in tomato have generated increased interest among the breeders for the last few years. The commercial exploitation of hybrid vigor has received greater importance on account of several advantages of hybrids over pure line varieties with response to marketable fruit yield and its component traits.

The most important problems facing horizontal expansion of tomato is water shortage especially in the new reclaimed lands. Where, deficit irrigation had an opposite influences on many aspects of plants physiology, water balance, nutrient, absorption and consequently photosynthetic capacity so that, plant growth (Ibrahim, 2005; Harmanto et al., 2005; Sibomana et al., 2013) and production are severely decreased (Birhanu and Tilahun, 2010; Panigrahi et al., 2010; Aksic et al. 2011 and Olanik and Madramootoo, 2014). So, drought is a major limiting factor in the production of tomato in many areas of the world including Egypt and there is considerable interest in trying to increase drought tolerance in tomato. Improving drought tolerance is, therefore, a major objective in plant breeding programs for the new reclaimed lands. Knowledge of genetic behavior and type of gene action controlling target traits is a basic principle for designing an appropriate breeding procedure for the purpose of genetic improvement. Hence, the success of any selection or hybridization breeding program for developing drought-tolerant varieties depends on precise estimates of genetic variation components for traits of interest consisting of additive, dominant and non-allelic interaction effects (Farshadfar et al., 2008; Nouri et al., 2011).

The main objectives of the present investigation was assessing the variation amongst 6 genotypes and their available crosses for drought and normal conditions as well as estimate the magnitude of heterosis to improve tomato productivity under drought condition.

\section{Materials and Methods}

The present study was carried out in a private farm, Kaha city, Kalyobiya Governorate, Egypt during summer seasons of 2015 and 2016 to study the genetic behavior of some economic traits for six tomato cultivars grown under normal irrigation and drought stress. This investigation was a half diallel $F_{1}$ cross experiment to induce genetic variability by hybridization and evaluation and selection for best 
genotypes of tomato compared with the parents under drought conditions and normal irrigation.

The six parental genotypes of tomato (Solanum Lycopersicom), i.e. Tan Shit Star $\left(\mathrm{p}_{1}\right)$, Real Stone $\left(\mathrm{p}_{2}\right)$, Pearsone $\operatorname{Imp}\left(\mathrm{p}_{3}\right)$, Super marmande $\left(\mathrm{p}_{4}\right)$, Tomato Golden $\left(\mathrm{p}_{5}\right)$ and Peto mech $\left(\mathrm{p}_{6}\right)$ and their $\mathrm{F}_{1 \mathrm{~s}}$ hybrids were planted in successive summer plantings of 2016 under open field conditions. Two adjacent experiments were conducted. Where, the first experiment was irrigated every month (environment 1) and the second one was normally irrigated, i.e., every 2 week (environment 2). Each experiment was designed in a randomized complete block design (R.C.B.D) with three replications. Each replication block had 21 plots (seven parental verities and their 15 $F_{1}$ hybrids under either drought or normal irrigation).

Three plants were selected excluding border plants for recording the observation. These observations were in yield traits viz., fruits number and total yield per plant as well as fruit traits viz., average fruit weight, fruit length, fruit diameter, total soluble solids percentage (According to A.O.A.C., 1990), total sugars (According to Flood and Priestly, 1973)and total polyphenol $\mathrm{mg}$ (10 .g f.w) content in the fruit.

The data of the two experiments were subjected to proper statistical analysis of variance according to Snedecor and Cochran (1967). The combined analysis was conducted for the data of the two experiments according to Cochran and Cox (1957).
Heterosis for each trait was computed as parents vs. crosses sum of squares obtained by partitioning the genotypes sum of square to its components. In this procedure, genotypes were subdivided to parents, crosses, and parents vs. crosses. This procedure made it possible to test the significance of the probable heterosis as an average overall the studied crosses.

Heterosis was also determined for individual crosses according to Paschal and Wilcox (1975) as the percentage deviation of $F_{1}$ mean performances from either the mid-parent value (MP) or better parent mean (BP) for $F_{1}$ date of each experiment as well as the combined analysis as follows:

$$
\begin{aligned}
& \text { Mid-parent heterosis }=\frac{\overline{\mathrm{F}} \overline{\mathrm{L}}-\mathrm{M} \overline{\mathrm{P}}}{\mathrm{M} \overline{\mathrm{P}}} \times 100 ; \text { Better } \\
& \text { parent heterosis }=\frac{\mathrm{F} 1-\mathrm{B} \overline{\mathrm{P}}}{\mathrm{B} \overline{\mathrm{P}}} \times 100
\end{aligned}
$$

\section{Results and Discussion}

\section{Mean performance:}

Data presented in Table 1 show that the highest number of fruits was detected for the parent $\mathrm{P}_{5}(55.92$, 70.00 and 62.96 fruits/plant under drought stress, normal irrigation and combined data, respectively).

Table 1. Mean performance of the genotypes for some flowering and yield traits under drought stress and normal

\begin{tabular}{|c|c|c|c|c|c|c|}
\hline \multirow[b]{2}{*}{ Genotypes } & \multicolumn{3}{|c|}{ Number of fruits / plant } & \multicolumn{3}{|c|}{ Total fruit yield (kg/plant) } \\
\hline & Drought & Normal & Combined & Drought & Normal & Combined \\
\hline $\mathrm{P}_{1}$ & 30.92 & 41.63 & 36.27 & 1.95 & 2.76 & 2.35 \\
\hline $\mathrm{P}_{2}$ & 44.83 & 51.92 & 48.38 & 1.99 & 2.18 & 2.08 \\
\hline $\mathrm{P}_{3}$ & 25.75 & 33.67 & 29.71 & 1.91 & 2.85 & 2.38 \\
\hline $\mathrm{P}_{4}$ & 23.58 & 28.42 & 26.00 & 1.94 & 2.10 & 2.02 \\
\hline $\mathrm{P}_{5}$ & 55.92 & 70.00 & 62.96 & 1.48 & 1.99 & 1.74 \\
\hline $\mathrm{P}_{6}$ & 42.67 & 71.83 & 57.25 & 2.71 & 2.58 & 2.65 \\
\hline $\mathrm{P}_{1} \times \mathrm{P}_{2}$ & 44.67 & 48.83 & 46.75 & 2.22 & 2.42 & 2.32 \\
\hline $\mathrm{P}_{1} \times \mathrm{P}_{3}$ & 32.17 & 33.00 & 32.58 & 1.91 & 2.54 & 2.22 \\
\hline $\mathrm{P}_{1} \times \mathrm{P}_{4}$ & 45.92 & 61.75 & 53.83 & 3.05 & 3.54 & 3.29 \\
\hline $\mathrm{P}_{1} \times \mathrm{P}_{5}$ & 36.83 & 38.50 & 37.67 & 2.29 & 2.69 & 2.49 \\
\hline $\mathrm{P}_{1} \times \mathrm{P}_{6}$ & 46.17 & 59.83 & 53.00 & 3.24 & 3.27 & 3.25 \\
\hline $\mathrm{P}_{2} \mathrm{XP}_{3}$ & 43.21 & 50.58 & 46.90 & 2.76 & 3.42 & 3.09 \\
\hline $\mathrm{P}_{2} \mathrm{XP}_{4}$ & 34.25 & 48.75 & 41.50 & 2.72 & 2.07 & 2.39 \\
\hline $\mathrm{P}_{2} \mathrm{XP}_{5}$ & 39.33 & 43.58 & 41.46 & 2.95 & 3.10 & 3.02 \\
\hline $\mathrm{P}_{2} \mathrm{XP}_{6}$ & 35.00 & 43.92 & 39.46 & 2.50 & 2.84 & 2.67 \\
\hline $\mathrm{P}_{3} \mathrm{XP}_{4}$ & 30.97 & 34.56 & 32.77 & 2.13 & 2.69 & 2.41 \\
\hline $\mathrm{P}_{3} \times \mathrm{P}_{5}$ & 18.50 & 27.25 & 22.88 & 1.69 & 2.47 & 2.08 \\
\hline $\mathrm{P}_{3} \mathrm{xP}_{6}$ & 27.42 & 30.00 & 28.71 & 2.16 & 2.34 & 2.25 \\
\hline $\mathrm{P}_{4} \times \mathrm{P}_{5}$ & 42.42 & 56.50 & 49.46 & 2.08 & 2.65 & 2.37 \\
\hline $\mathrm{P}_{4} \mathrm{XP}_{6}$ & 41.17 & 47.92 & 44.54 & 1.90 & 2.30 & 2.10 \\
\hline $\mathrm{P}_{5} \mathrm{xP}_{6}$ & 77.17 & 81.33 & 79.25 & 2.62 & 3.00 & 2.81 \\
\hline $\mathrm{LSD}_{5 \%}$ & 8.25 & 8.39 & 8.13 & 0.31 & 0.46 & 0.38 \\
\hline $\mathrm{LSD}_{1 \%}$ & 11.03 & 11.06 & 10.74 & 0.42 & 0.61 & 0.51 \\
\hline
\end{tabular}
irrigation $(\mathrm{N})$ as well as the combined data $(\mathrm{C})$.

However, parent $\mathrm{P}_{4}$ gave the lowest number of fruits with values of 23.58, 28.42 and 26.00 fruits/plant under drought condition, normal irrigation and combined analysis, respectively. 
Concerning the crosses, the highest number of fruits was detected for the cross $\mathrm{P}_{5} \mathrm{xP}_{6}$ in drought condition, normal irrigation and combined analysis with values of $77.17,81.33$ and 79.25 , respectively. However, the lowest number of fruits was recorded for the cross $\mathrm{P}_{3} \mathrm{XP}_{5}$ under drought condition, normal irrigation and combined analysis with values of 18.50 , 27.25 and 22.88, respectively. High mean performance for the number of fruits have been also reported by Rattan (2007), Abdelmageed and Gruda (2009), Droka et al. (2013), Mehboob et al. (2015) as well as Alam $\boldsymbol{e t}$ al. (2010), Wahb-Allah $\boldsymbol{e t}$ al. (2011) and Sacco et al. (2013).

Furthermore, $\mathrm{P}_{6}$ gave the highest values for total yield per plant, i.e. 2.71 and $2.65 \mathrm{~kg} /$ plant under drought stress and combined analysis, respectively while parent $\mathrm{P}_{5}$ recorded the lowest values, i.e. 1.48, 1.99 and $1.74 \mathrm{~kg} /$ plant under drought stress, normal irrigation and combined analysis, respectively. The cross $\mathrm{P}_{1} \mathrm{xP}_{4}$ and $\mathrm{P}_{1} \times \mathrm{P}_{6}$ expressed the highest values for total yield per plant under drought stress (3.05 and $3.24 \mathrm{~kg} / \mathrm{plant}$, respectively), normal irrigation (3.54 and $3.27 \mathrm{~kg} / \mathrm{plant}$, respectively) and combined analysis (3.29 and $3.25 \mathrm{~kg} / \mathrm{plant}$, respectively). The genetic differences in number of fruits among tomato genotypes have been reported by Rattan (2007), Abdelmageed and Gruda (2009), Mehboob et al. (2015) and Shakil et al. (2017) as well as Rehman et al. (2000), Alam et al. (2010), Wahb-Allah et al. (2011) and Sacco et al. (2013) under stress conditions.
Mean performance of the tested tomato parents and their $F_{1}$ hybrids under drought condition and normal irrigation as well as combined analysis for fruit length, diameter and weight, TSS, total sugars (\%) and total polyphenol contents are presented in Tables 2 and 3.

Concerning fruit length trait, the parental variety $\mathrm{P}_{2}$ and $\mathrm{P}_{3}$ exhibited the highest mean value for fruit length under drought stress and normal irrigation as well as combined analysis. However, the parent $\mathrm{P}_{5}$ gave the lowest mean values under all environments. Results also indicated that the crosses $\mathrm{P}_{2} \mathrm{XP}_{3}, \mathrm{P}_{2} \mathrm{XP}_{5}$ and $\mathrm{P}_{2} \mathrm{XP}_{6}$ exhibited the highest mean values for fruit length under stress, non-stress conditions and the combined analysis, respectively (Adhi et al. (2014)). For fruit diameter, the parental variety $\mathrm{P}_{4}$ gave the highest mean values for current trait recording 5.15, 5.87 and $5.51 \mathrm{~cm}$ under drought treatment, normal irrigation and combined analysis, respectively. While, $\mathrm{P}_{5}$ gave the lowest values, i.e., 3.37 and $3.82 \mathrm{~cm}$ under drought treatment and combined analysis, respectively. The cross $\mathrm{P}_{3} \mathrm{XP}_{5}$ expressed the highest means value being $5.50 \mathrm{~cm}$ under stress condition. Whereas, the cross $\mathrm{P}_{1} \mathrm{xP}_{3}$ gave the highest values for this trait in normal irrigation treatment $(7.50 \mathrm{~cm})$ and combined data $(6.07 \mathrm{~cm})$. However, $\mathrm{P}_{1} \mathrm{XP}_{2}$ recorded the lowest values under drought treatment and combined analysis with values of $3.75,3.93$ and 3.84 , respectively.

Table 2. Mean performance of the genotypes for fruit length, fruit diameter and average fruit weight traits under drought stress (D) and normal irrigation (N) as well as the combined data (C).

\begin{tabular}{|c|c|c|c|c|c|c|c|c|c|}
\hline \multirow[b]{2}{*}{ Genotypes } & \multicolumn{3}{|c|}{ Fruit length } & \multicolumn{3}{|c|}{ Fruit diameter } & \multicolumn{3}{|c|}{ Average fruit weight } \\
\hline & D & $\mathbf{N}$ & C & D & $\mathbf{N}$ & C & D & $\mathbf{N}$ & C \\
\hline $\mathbf{P}_{1}$ & 4.63 & 5.07 & 4.85 & 4.28 & 5.13 & 4.71 & 62.98 & 66.20 & 64.59 \\
\hline $\mathbf{P}_{2}$ & 4.93 & 5.23 & 5.08 & 3.97 & 4.07 & 4.02 & 41.90 & 44.44 & 43.17 \\
\hline $\mathbf{P}_{3}$ & 4.00 & 5.50 & 4.75 & 3.85 & 6.83 & 5.34 & 74.24 & 84.91 & 79.57 \\
\hline $\mathbf{P}_{4}$ & 3.47 & 4.17 & 3.82 & 5.15 & 5.87 & 5.51 & 73.97 & 82.35 & 78.16 \\
\hline $\mathbf{P}_{5}$ & 2.93 & 3.77 & 3.35 & 3.37 & 4.27 & 3.82 & 26.44 & 28.47 & 27.46 \\
\hline $\mathbf{P}_{6}$ & 4.22 & 5.40 & 4.81 & 3.78 & 4.83 & 4.31 & 37.81 & 60.27 & 49.04 \\
\hline $\mathbf{P}_{1} \mathbf{x} \mathbf{P}_{2}$ & 4.92 & 5.60 & 5.26 & 3.75 & 3.93 & 3.84 & 45.42 & 54.13 & 49.78 \\
\hline $\mathbf{P}_{1} \mathbf{x} \mathbf{P}_{3}$ & 3.72 & 4.67 & 4.19 & 4.63 & 7.50 & 6.07 & 59.59 & 76.98 & 68.28 \\
\hline $\mathbf{P}_{1} \mathbf{P P}_{4}$ & 3.72 & 4.13 & 3.93 & 4.22 & 5.23 & 4.73 & 49.48 & 77.09 & 63.28 \\
\hline $\mathbf{P}_{1} \mathbf{x} \mathbf{P}_{5}$ & 5.08 & 5.23 & 5.16 & 5.12 & 5.00 & 5.06 & 62.64 & 69.75 & 66.20 \\
\hline $\mathbf{P}_{1} \mathbf{P P}_{6}$ & 4.27 & 4.67 & 4.47 & 4.17 & 4.33 & 4.25 & 54.19 & 70.76 & 62.48 \\
\hline $\mathbf{P}_{2} \mathbf{x} \mathbf{P}_{3}$ & 5.10 & 5.43 & 5.27 & 4.82 & 5.37 & 5.09 & 63.98 & 67.66 & 65.82 \\
\hline $\mathbf{P}_{2} \mathrm{XP}_{4}$ & 4.57 & 4.83 & 4.70 & 4.70 & 4.93 & 4.82 & 55.77 & 60.57 & 58.17 \\
\hline $\mathbf{P}_{2} \times P_{5}$ & 5.00 & 5.67 & 5.33 & 5.10 & 5.33 & 5.22 & 71.04 & 75.03 & 73.04 \\
\hline $\mathbf{P}_{2 \times P_{6}}$ & 4.67 & 5.83 & 5.25 & 4.88 & 4.93 & 4.91 & 57.00 & 81.29 & 69.15 \\
\hline $\mathbf{P}_{3 \times P}$ & 4.31 & 5.12 & 4.71 & 4.82 & 6.38 & 5.60 & 71.85 & 80.21 & 76.03 \\
\hline $\mathbf{P}_{3} \mathbf{x} \mathbf{P}_{5}$ & 4.73 & 4.80 & 4.77 & 5.50 & 5.67 & 5.58 & 90.81 & 91.30 & 91.06 \\
\hline $\mathbf{P}_{3} \times P_{6}$ & 3.70 & 5.57 & 4.63 & 4.17 & 7.17 & 5.67 & 72.52 & 85.39 & 78.96 \\
\hline $\mathbf{P}_{4} \times P_{5}$ & 3.63 & 4.17 & 3.90 & 3.17 & 5.67 & 4.42 & 36.83 & 62.58 & 49.70 \\
\hline $\mathbf{P}_{4} \times P_{6}$ & 3.93 & 5.43 & 4.68 & 4.17 & 4.53 & 4.35 & 39.82 & 55.81 & 47.82 \\
\hline $\mathbf{P}_{5 \times P_{6}}$ & 4.27 & 4.73 & 4.50 & 4.33 & 4.87 & 4.60 & 32.21 & 38.80 & 35.50 \\
\hline LSD $5 \%$ & 0.06 & 0.03 & 0.05 & 0.11 & 0.02 & 0.08 & 3.94 & 2.02 & 3.07 \\
\hline LSD $_{1 \%}$ & 0.08 & 0.04 & 0.06 & 0.15 & 0.03 & 0.11 & 5.27 & 2.66 & 4.06 \\
\hline
\end{tabular}


Regarding average fruit weight, the parent $\mathrm{P}_{3}$ expressed the highest mean values for average fruit weight recording $74.24,84.91$ and $79.57 \mathrm{~g}$ in the drought, normal irrigation and combined analysis, respectively. Meanwhile, parent $\mathrm{P}_{5}$ gave the lowest mean values for average fruit weight being 26.44, 28.47 and $27.46 \mathrm{~g}$ in the drought, normal irrigation and combined analysis, respectively. Moreover, the cross $\mathrm{P}_{3} \mathrm{XP}_{5}$ exhibited the highest mean values for average fruit weight recording 90.81, 91.30 and $91.06 \mathrm{~g}$ in the drought, normal irrigation and combined analysis, respectively. Whereas, the cross $\mathrm{P}_{4} \mathrm{XP}_{6}$ gave the lowest mean values being $32.21,38.80$ and $35.50 \mathrm{~g}$ in the drought, normal irrigation and combined analysis, respectively. These results are agreed with those of Dhaliwal et al. (2003), Sharma and Thakur (2007), Gul et al. (2010), Adhi et al. (2014).

For TSS \%, the parental variety $\mathrm{P}_{5}$ exhibited the highest mean value for fruit TSS under drought stress and normal irrigation as well as combined analysis. Results also indicated that the crosses $\mathrm{P}_{2} \mathrm{XP}_{3}$ and $\mathrm{P}_{2} \mathrm{XP}_{5}$ exhibited the highest mean values for fruit TSS under all conditions. This finding in agreement with this reported by Bhnan (2002), Gaikwad et al. (2002), Singh el al. (2007).

Table 3. Mean performance of the genotypes for TSS, total sugars (\%) and total polyphenol mg (10 .g f.w) traits under drought stress (D) and normal irrigation $(\mathrm{N})$ as well as the combined data (C) .

\begin{tabular}{|c|c|c|c|c|c|c|c|c|c|}
\hline \multirow[b]{2}{*}{ Genotypes } & \multicolumn{3}{|c|}{ TSS } & \multicolumn{3}{|c|}{ Total sugars (\%) } & \multicolumn{3}{|c|}{$\begin{array}{c}\text { Total polyphenol mg (10 .g } \\
\text { f.w) }\end{array}$} \\
\hline & D & $\mathbf{N}$ & $\mathbf{C}$ & D & $\mathbf{N}$ & $\mathbf{C}$ & D & $\mathbf{N}$ & $\mathbf{C}$ \\
\hline $\mathbf{P}_{1}$ & 4.00 & 3.00 & 3.50 & 2.97 & 2.22 & 2.59 & 37.50 & 32.10 & 34.80 \\
\hline $\mathbf{P}_{2}$ & 4.00 & 3.25 & 3.63 & 2.33 & 1.76 & 2.05 & 37.40 & 19.30 & 28.35 \\
\hline $\mathbf{P}_{3}$ & 4.00 & 3.75 & 3.88 & 2.47 & 2.17 & 2.32 & 32.33 & 26.57 & 29.45 \\
\hline $\mathbf{P}_{4}$ & 4.00 & 3.25 & 3.63 & 2.37 & 2.12 & 2.25 & 43.23 & 23.57 & 33.40 \\
\hline $\mathbf{P}_{5}$ & 4.25 & 4.00 & 4.13 & 2.57 & 1.88 & 2.23 & 26.37 & 15.20 & 20.78 \\
\hline $\mathbf{P}_{6}$ & 3.25 & 3.00 & 3.13 & 1.73 & 1.57 & 1.65 & 37.43 & 25.13 & 31.28 \\
\hline $\mathbf{P}_{1} \mathbf{x} \mathbf{P}_{2}$ & 4.00 & 3.25 & 3.63 & 1.83 & 1.71 & 1.77 & 52.27 & 27.30 & 39.78 \\
\hline $\mathbf{P}_{1} \mathbf{P P}_{3}$ & 4.00 & 3.00 & 3.50 & 2.72 & 1.14 & 1.93 & 21.27 & $\mathbf{1 7 . 3 7}$ & 19.32 \\
\hline $\mathbf{P}_{1 \times P_{4}}$ & 3.75 & 3.50 & 3.63 & 2.70 & 1.62 & 2.16 & 34.23 & 32.20 & 33.22 \\
\hline $\mathbf{P}_{1 \times P_{5}}$ & 4.00 & 3.25 & 3.63 & 2.16 & 1.70 & 1.93 & 46.07 & 19.13 & 32.60 \\
\hline $\mathbf{P}_{1 \times P_{6}}$ & 4.00 & 3.75 & 3.88 & 2.41 & 1.77 & 2.09 & 39.20 & 35.23 & 37.22 \\
\hline $\mathbf{P}_{2} \mathbf{x} \mathbf{P}_{3}$ & 4.00 & 3.00 & 3.50 & 2.23 & 1.77 & 2.00 & 37.47 & 26.10 & 31.78 \\
\hline $\mathbf{P}_{2} \mathbf{x} \mathbf{P}_{4}$ & 3.00 & 3.00 & 3.00 & 2.54 & 2.10 & 2.32 & 26.47 & 26.33 & 26.40 \\
\hline $\mathbf{P}_{2} \times P_{5}$ & 3.00 & 2.75 & 2.88 & 2.72 & 1.78 & 2.25 & 37.17 & 29.70 & 33.43 \\
\hline $\mathbf{P}_{2} \times P_{6}$ & 3.50 & 3.00 & 3.25 & 2.47 & 1.55 & 2.01 & 29.67 & 27.37 & 28.52 \\
\hline $\mathbf{P}_{3} \times P_{4}$ & 4.25 & 3.44 & 3.84 & 1.51 & 1.30 & 1.40 & 33.87 & 26.68 & 30.27 \\
\hline $\mathbf{P}_{3} \mathbf{x} \mathbf{P}_{5}$ & 4.00 & 3.75 & 3.88 & 1.18 & 1.02 & 1.10 & 40.43 & 37.37 & 38.90 \\
\hline $\mathbf{P}_{3} \times P_{6}$ & 5.00 & 4.00 & 4.50 & 1.25 & 1.15 & 1.20 & 36.30 & 25.87 & 31.08 \\
\hline $\mathbf{P}_{4} \times P_{5}$ & 3.75 & 2.25 & 3.00 & 2.32 & 1.83 & 2.07 & 36.13 & 35.40 & 35.77 \\
\hline $\mathbf{P}_{4 x} P_{6}$ & 4.00 & 3.25 & 3.63 & 2.32 & 2.10 & 2.21 & 22.20 & 17.47 & 19.83 \\
\hline$P_{5 x} P_{6}$ & 5.25 & 3.25 & 4.25 & 3.33 & 1.81 & 2.57 & 34.10 & 21.67 & 27.88 \\
\hline LSD $5 \%$ & 0.32 & 0.29 & 0.30 & 0.23 & 0.13 & 0.18 & 0.53 & 0.49 & 0.50 \\
\hline LSD $_{1 \%}$ & 0.42 & 0.39 & 0.39 & 0.31 & 0.16 & 0.24 & 0.71 & 0.65 & 0.66 \\
\hline
\end{tabular}

Concerning total sugars $(\%)$, the highest values of total sugars $(\%)$ were detected for the parent $\mathrm{P}_{1}(4.28$, 5.13 and 4.71 under drought stress, normal irrigation and combined data, respectively). However, the highest values of total sugars (\%) were detected for the crosses $\mathrm{P}_{2} \mathrm{XP}_{5}, \mathrm{P}_{2} \mathrm{XP}_{4}$ and $\mathrm{P}_{5} \mathrm{xP}_{6}$ in drought condition, normal irrigation and combined analysis, respectively. Regarding the total polyphenol contents, the parental variety $\mathrm{P}_{4}$ gave the highest mean value for current trait under drought treatment while, $\mathrm{P}_{1}$ gave the highest mean value under normal irrigation and combined analysis, respectively. The cross $\mathrm{P}_{3} \mathrm{xP}_{5}$ expressed the highest means values being 90.81, 91.30 and 91.06 under drought treatment, normal irrigation and combined analysis, respectively.

\section{Heterosis:}

Data presented in Table 4 show heterosis relative to mid parent and better parent for number of fruits and total yield per plant under normal irrigation and drought stress as well as the combined over them. Regarding number of fruits /plant, 3, 3 and 2 crosses expressed significant or highly significant and positive heterosis relative to mid parent in drought condition, normal irrigation and combined analysis, respectively. However, the cross $\mathrm{P}_{1} \times \mathrm{P}_{4}$ gave the best heterotic effect under drought condition, normal irrigation and combined analysis being 68.5, 76.32 and 72.9, respectively. Moreover, highly significant and positive better parent heterosis were detected in 3 , 2 and 2 crosses in drought stress, normal irrigation and combined analysis, respectively. However, the cross $\mathrm{P}_{1} \times \mathrm{P}_{4}$ gave the best heterotic effect under drought condition, normal irrigation and combined analysis 
being 48.52, 48.35 and 48.42, respectively. It is clear that the cross $\mathrm{P}_{1} \times \mathrm{P}_{4}$ expressed the highest desirable heterosis relative to mid parent and better parent in the two environments treatments and combined analysis of them. Significant and positive heterosis effects for number of fruits per plant were detected by Souza $\boldsymbol{e t}$ al. (2012), Solieman et al. (2013), Adhi et al. (2014), Dissanayaka et al. (2014), Mehboob et al. (2015), Aisyah et al. (2016), Marbhal et al. (2016) as well as Anita et al. (2013) under stress conditions.

Regarding fruit yield per plant, 8, 7 and 7 crosses expressed significant or highly significant and positive heterosis relative to mid parent in drought condition, normal irrigation and combined analysis, respectively. Where, the cross $\mathrm{P}_{2} \times \mathrm{P}_{5}$ gave the best heterotic effect under drought condition, normal irrigation and combined analysis being 70.11, 48.58 and 58.36, respectively. Concerning heterosis relative to better parent, only cross $\mathbf{P}_{\mathbf{1}} \mathbf{P}_{4}$ exhibited significant and positive heterosis under only drought stress $\left(56.35^{*}\right)$. Significant and positive heterosis were also reported by Ahmed et al. (2011), Kumari and Sharma (2011), Kumar et al. (2012), Rajan (2012), Singh et al. (2012), Souza et al. (2012), Solieman et al. (2013), Droka et al. (2013), Dissanayaka et al. (2014), Mehboob et al. (2015), Aisyah et al. (2016), Marbhal et al. (2016) and Shakil et al. (2017) as well as Aref and Abdul-Baki (1991), Borgohain and Swargiary (2008), Anita et al. (2013) under stress conditions.

Heterosis relative to mid- and better- parent for fruit traits i.e., fruit length, diameter and weight as well as TSS, total sugars (\%) and total polyphenol contents under drought stress and normal irrigation as well as combined analysis are presented in Tables 5, 6 and 7. Data presented in Table 5 show that 11, 12 and 11 crosses expressed highly significant and positive heterosis effects relative to mid parent for fruit length in drought treatment, normal irrigation and combined analysis, respectively. Also, 3, 3 and 2 crosses exhibited significant and positive better parent heterosis in the same order. However, the most desirable mid parent heterosis effects were detected for the crosses $\mathrm{P}_{3} \times \mathrm{P}_{5}$ (36.54), $\mathrm{P}_{1} \times \mathrm{P}_{5}$ (18.49), and $\mathrm{P}_{2}$ $x \mathrm{P}_{5}$ (26.48) in drought stress, normal irrigation and combined analysis, respectively. The most desirable heterotic effects relative to better parent were detected for the crosses $\mathrm{P}_{3} \times \mathrm{P}_{5}$ in drought condition, $\mathrm{P}_{2} \times \mathrm{P}_{5}$ in normal irrigation; and $\mathrm{P}_{2} \times \mathrm{P}_{5}$ in the combined analysis being 19.25, 7.87 and 6.42, respectively (Table, 5). In this respect, Kurian et al. (2001), Gul et al. (2010), Rahmani et al. (2010), Adhi et al. (2014), Dagade $e t$ al. (2015), Kumar and Singh (2016), Shakil et al. (2017) and Singh and Kumar (2017) detected significant and positive heterosis effects for fruit length.

Concerning fruit diameter, 9, 10 and 9 crosses expressed significant or highly significant and positive heterosis effects relative to mid parent in drought treatment, normal irrigation and combined analysis, respectively. Where, the most desirable heterotic effects relative to better parent were detected for the crosses $\mathrm{P}_{1} \times \mathrm{P}_{5}$ in drought condition, normal irrigation and the combined analysis being 40.19, 23.33 and 26.75, respectively. However, the cross $\mathrm{P}_{3}$ $\mathrm{x} \mathrm{P}_{5}$ was the only cross that expressed highly significant and positive heterosis in drought stress (18.33), whereas the crosses $\mathrm{P}_{2} \times \mathrm{P}_{5}$ and gave the significant and positive hetertotic effects relative to better parent (8.28 and 8.02, respectively) in the normal irrigation (Table, 5). Significant and positive mid-parent and better- parent heterosis for fruit diameter was reported by Kurian et al. (2001), Kumar and Singh (2016) and Singh and Kumar (2017).

Data presented in Table 6 show the heterosis relative to mid- and better- parent for fruit weight and T.S.S. content under drought stress, normal irrigation and combined analysis. Results indicated that 5,9 and 7 crosses expressed highly significant and positive heterosis effects relative to mid parent in drought treatment, normal irrigation and combined analysis, respectively. Among these crosses which recorded highly significant and positive heterosis over mid parent, 3, 5 and 3 crosses exhibited significant or highly significant and positive better parent heterosis in the same order. However, the most desirable mid and better parent heterosis effects were detected for the crosses $\mathrm{P}_{2} \times \mathrm{P}_{5}$ in drought stress, normal irrigation and combined analysis. In this concern Kurian et al. (2001), Joshi and Thakur (2003), Tiwari and Lal (2004), Asati et al. (2007), Sharma and Thakur (2007), Kumar et al. (2012) and Adhi et al. (2014) found significant and positive mid-parent and betterparent heterosis for fruit weight.

Regarding T.S.S, 4, 4 and 3 crosses expressed significant highly significant and positive heterosis effects relative to mid parent in drought treatment, normal irrigation and combined analysis, respectively. Where, the most desirable mid parent heterosis effects were detected for the crosses $\mathrm{P}_{5} \times \mathrm{P}_{6}$ (40), $\mathrm{P}_{1} \times \mathrm{P}_{6}$ (25), and $\mathrm{P}_{3} \times \mathrm{P}_{6}$ (28.57) in drought stress, normal irrigation and combined analysis, respectively. However, only the crosses $\mathrm{P}_{3} \times \mathrm{P}_{6}$ and $\mathrm{P}_{5} \times \mathrm{P}_{6}$ exhibited significant and positive better parent heterosis only the drought stress being 25and 23.53, respectively. Significant and positive heterosis for fruit TSS was reported by Sharma et al. (2001), Bhnan (2002), Tiwari and Lal (2004), Duhan et al. (2005), Kumar et al. (2013), Adhi et al. (2014) and Singh and Kumar (2017) as well as Ahmed et al. (2011) and Chattopadhyay $\boldsymbol{e t}$ al. (2012) under stress conditions.

Concerning total sugars contents, 4, 2 and 2 crosses expressed significant or highly significant and positive heterosis effects relative to mid parent in drought treatment, normal irrigation and combined analysis, respectively, as shown in Table 7. 
Table 4. Heterosis relative to mid parent and better parent for number of fruits and total yield per plant under normal irrigation (N) and drought stress (D) as well as the combined over them $(\mathrm{C})$

\begin{tabular}{|c|c|c|c|c|c|c|c|c|c|c|c|c|}
\hline \multirow{3}{*}{ Cross } & \multicolumn{6}{|c|}{ Number of fruits / plant } & \multicolumn{6}{|c|}{ Total fruit yield } \\
\hline & \multicolumn{3}{|c|}{ Mid Parent (M.P) } & \multicolumn{3}{|c|}{ Better Parent ( B.P) } & \multicolumn{3}{|c|}{ Mid Parent (M.P) } & \multicolumn{3}{|c|}{ Better Parent ( B.P) } \\
\hline & Drought & Normal & Combined & Drought & Normal & Combined & Drought & Normal & Combined & Drought & Normal & Combined \\
\hline $\mathbf{P}_{1} \mathbf{x} \mathbf{P}_{2}$ & 17.93 & 4.41 & 10.46 & -0.37 & -5.94 & -3.36 & 12.76 & -1.99 & 4.56 & 11.55 & -12.31 & -1.41 \\
\hline $\mathbf{P}_{1} \mathbf{x} \mathbf{P}_{3}$ & 13.53 & -12.34 & -1.23 & 4.04 & $-20.72 * *$ & -10.17 & -1.01 & -9.52 & -6.05 & -1.91 & -11.08 & -6.67 \\
\hline $\mathbf{P}_{1} \times P_{4}$ & $68.5 * *$ & $76.32 * *$ & $72.9 * *$ & $48.52 * *$ & $48.35 * *$ & $48.42 * *$ & $56.55 * *$ & $45.75 * *$ & $50.55 * *$ & $56.35 *$ & 28.43 & 39.99 \\
\hline $\mathbf{P}_{1 \times P_{5}}$ & -15.16 & $-31.02 * *$ & $-24.08 * *$ & $-34.13 * *$ & $-45 * *$ & $-40.17 * *$ & $33.92 * *$ & 13.31 & $21.95 *$ & 17.82 & -2.39 & 5.98 \\
\hline $\mathbf{P}_{1} \mathbf{x} \mathbf{P}_{6}$ & $25.48^{*}$ & 5.47 & 13.34 & 8.2 & $-16.71 * *$ & -7.42 & $39.11 * *$ & $22.51 *$ & $30.25 * *$ & 19.47 & 18.53 & 23.02 \\
\hline $\mathbf{P}_{2} \mathbf{x} \mathbf{P}_{3}$ & 22.43 & 18.21 & 20.12 & -3.62 & -2.57 & -3.06 & $41.68 * *$ & $36.08 * *$ & $38.53 * *$ & 38.88 & 19.89 & 29.79 \\
\hline $\mathbf{P}_{2} \times P_{4}$ & 0.12 & $21.37^{*}$ & 11.6 & $-23.61 * *$ & -6.1 & $-14.21 * *$ & $38.12 * *$ & -3.02 & 16.69 & 36.45 & -4.67 & 14.98 \\
\hline $\mathbf{P}_{2} \times P_{5}$ & $-21.92 * *$ & $-28.5 * *$ & $-25.52 * *$ & $-29.66 * *$ & $-37.74 * *$ & $-34.15^{* *}$ & $70.11 * *$ & $48.58 * *$ & $58.36 * *$ & 48.26 & 42.34 & 45.17 \\
\hline $\mathbf{P}_{2} \times P_{6}$ & $-20 *$ & $-29.02 * *$ & $-25.29 * *$ & $-21.93 * *$ & $-38.86 * *$ & $-31.08 * *$ & 6.38 & $19.72 *$ & 13.08 & -7.8 & 10.39 & 1.06 \\
\hline $\mathbf{P}_{3} \mathbf{x} \mathbf{P}_{4}$ & 25.55 & 11.34 & 17.63 & $20.27 *$ & 2.66 & 10.29 & 10.57 & 8.72 & 9.53 & 9.71 & -5.63 & 1.22 \\
\hline $\mathbf{P}_{3 \times P_{5}}$ & $-54.69 * *$ & $-47.43 * *$ & $-50.63^{* *}$ & $-66.92 * *$ & $-61.07 * *$ & $-63.67 * *$ & -0.6 & 2.1 & 0.99 & -11.85 & -13.32 & -12.73 \\
\hline $\mathbf{P}_{3} \times \mathbf{P}_{6}$ & -19.85 & $-43.13 * *$ & $-33.97 * *$ & $-35.74 * *$ & $-58.24 * *$ & $-49.85 * *$ & -6.46 & -13.82 & -10.43 & -20.28 & -18.01 & -14.87 \\
\hline $\mathbf{P}_{4} \times P_{5}$ & 6.71 & 14.82 & 11.19 & $-24.14^{* *}$ & $-19.29 * *$ & $-21.44^{* *}$ & $21.63 *$ & $29.57 *$ & $25.96^{*}$ & 7.12 & 26.23 & 17.05 \\
\hline $\mathbf{P}_{4} \times P_{6}$ & 24.28 & -4.41 & 7.01 & -3.52 & $-33.29 * *$ & $-22.2 * *$ & $-18.36 * *$ & -1.79 & -10.06 & -29.97 & -10.86 & -20.66 \\
\hline $\mathbf{P}_{5 \times P_{6}}$ & $56.55 * *$ & 14.69* & $31.85 * *$ & $38 * *$ & $13.23 * *$ & $25.88 * *$ & $25.09 * *$ & $31.24 * *$ & $28.3 * *$ & -3.37 & 16.36 & 6.24 \\
\hline
\end{tabular}

$*$ and $* *$ significant at 0.05 and 0.01 levels of probability, respectively. 
Table 5. Heterosis relative to mid parent and better parent for fruit length and diameter under normal irrigation $(\mathrm{N})$ and drought stress (D) as well as the combined over them

\begin{tabular}{|c|c|c|c|c|c|c|c|c|c|c|c|c|}
\hline \multirow{3}{*}{ Cross } & \multicolumn{6}{|c|}{ Fruit length } & \multicolumn{6}{|c|}{ Fruit diameter } \\
\hline & \multicolumn{3}{|c|}{ Mid Parent (M.P) } & \multicolumn{3}{|c|}{ Better Parent ( B.P) } & \multicolumn{3}{|c|}{ Mid Parent (M.P) } & \multicolumn{3}{|c|}{ Better Parent ( B.P) } \\
\hline & Drought & Normal & Combined & Drought & Normal & Combined & Drought & Normal & Combined & Drought & Normal & Combined \\
\hline $\mathbf{P}_{1} \mathbf{x} \mathbf{P}_{2}$ & $2.79 * *$ & $8.74 * *$ & $5.87 * *$ & -0.35 & $6.66^{*}$ & 3.48 & $\mathbf{3 . 0 7}$ & $7.86 * *$ & 5.93 & -0.34 & 7.01 & 3.44 \\
\hline $\mathbf{P}_{1} \mathbf{x} \mathbf{P}_{3}$ & $-13.9 * *$ & $-11.67 * *$ & $-12.67 * *$ & $-20.77 * *$ & $-14.39 * *$ & $-13.71 * *$ & $-15.29 * *$ & $-10.5 * *$ & $-12.8 * *$ & $-19.78 * *$ & $-15.15 * *$ & $-13.57 * *$ \\
\hline $\mathbf{P}_{1} \mathbf{x} \mathbf{P}_{4}$ & $-8.23 * *$ & $-10.47 * *$ & $-9.42 * *$ & $-20.77 * *$ & $-17.5 * *$ & $-19.26 * *$ & $-9.05 * *$ & $-9.42 * *$ & $-9.52 * *$ & $-19.78 * *$ & $-18.42 * *$ & $-19.07 * *$ \\
\hline $\mathbf{P}_{1} \times P_{5}$ & $34.36 * *$ & $18.49 * *$ & $25.81 * *$ & $10.2 *$ & 3.13 & $6.42 *$ & $40.19 * *$ & $23.33 * *$ & $26.75 * *$ & $9.71 *$ & 3.29 & 6.36 \\
\hline $\mathbf{P}_{1} \mathbf{x} \mathbf{P}_{6}$ & $-\mathbf{3 . 5 8} * *$ & $-10.83 * *$ & $-7.51 * *$ & -8.31 & $-12.9 * *$ & -7.98 & $-3.94 * *$ & $-9.75 * *$ & $-7.58 * *$ & -7.91 & $-13.58 * *$ & -7.9 \\
\hline $\mathbf{P}_{2} \times P_{3}$ & $14.18 * *$ & $1.24 * *$ & $7.12 * *$ & 3.55 & -1.15 & 3.64 & $15.6 * *$ & 1.12 & $7.19 * *$ & 3.38 & -1.21 & 3.61 \\
\hline $\mathbf{P}_{2} \times P_{4}$ & $8.73 * *$ & $2.84 * *$ & $5.62 * *$ & -7.8 & -7.26 & -7.62 & $9.6^{* * *}$ & $2.55 * *$ & 5.67 & -7.43 & -7.64 & -7.54 \\
\hline $\mathbf{P}_{2} \times P_{5}$ & $27.12 * *$ & $25.93 * *$ & $26.48 * *$ & 1.42 & $7.87 *$ & 4.97* & $29.83 * *$ & $16.64 * *$ & $26.05 * *$ & 1.35 & 8.28* & 4.92 \\
\hline $\mathbf{P}_{2} \times P_{6}$ & $2 * *$ & $9.72 * *$ & $6.15 * *$ & -5.68 & $7.62 *$ & 3.31 & $2.2 * *$ & $8.75 * *$ & $6.21 *$ & -5.41 & 8.02* & 3.28 \\
\hline $\mathbf{P}_{3} \times P_{4}$ & $15.51 * *$ & $5.86 * *$ & $10.07 * *$ & $8.2 *$ & -6.62 & -0.75 & $17.06 * *$ & $5.28 * *$ & $10.17 * *$ & 7.81 & -6.97 & -0.75 \\
\hline $\mathbf{P}_{3} \times P_{5}$ & $36.54 * *$ & $3.6 * *$ & $17.7 * *$ & $19.25 * *$ & $-12.09 * *$ & 0.35 & $37.8 * *$ & $3.24 * *$ & $17.87 * *$ & $18.33 * *$ & $-12.73 * *$ & 0.35 \\
\hline $\mathbf{P}_{3 \times P_{6}}$ & $-9.94 * *$ & $2.14 * *$ & $-3.05 * *$ & $-12.87 *$ & 1.15 & -3.68 & $-10.93 * *$ & 1.93 & $-3.08 * *$ & $-12.25 *$ & 1.21 & -3.64 \\
\hline $\mathbf{P}_{4 \times} P_{5}$ & $13.54 * *$ & $5.04 * *$ & $8.84 * *$ & 5.05 & $\mathbf{0}$ & 2.21 & $14.9 * *$ & $4.54 * *$ & $8.93 * *$ & 4.81 & $\mathbf{0}$ & 2.18 \\
\hline $\mathbf{P}_{4 \times P_{6}}$ & $2.39 * *$ & $13.59 * *$ & $8.6 * *$ & -7.06 & 0.59 & -2.63 & 2.62 & $12.23^{* * *}$ & $8.69 * *$ & -6.72 & 0.62 & -2.6 \\
\hline $\mathbf{P}_{5} \times P_{6}$ & $19.35 * *$ & $3.27 * *$ & $10.32 * *$ & 1.25 & $-11.73 * *$ & -6.48 & $21.28 * *$ & $2.95 * *$ & $10.42 * *$ & 1.19 & $-12.35 * *$ & -6.41 \\
\hline
\end{tabular}

$*$ and ** significant at 0.05 and 0.01 levels of probability, respectively. 
Table 6. Heterosis relative to mid parent and better parent for fruit weight and T.S.S. content under normal irrigation (N) and drought stress (D) as well as the combined over them $(\mathrm{C})$.

\begin{tabular}{|c|c|c|c|c|c|c|c|c|c|c|c|c|}
\hline \multirow{3}{*}{ Cross } & \multicolumn{6}{|c|}{ Fruit weight } & \multicolumn{6}{|c|}{ T.S.S. } \\
\hline & \multicolumn{3}{|c|}{ Mid Parent (M.P) } & \multicolumn{3}{|c|}{ Better Parent ( B.P) } & \multicolumn{3}{|c|}{ Mid Parent (M.P) } & \multicolumn{3}{|c|}{ Better Parent ( B.P) } \\
\hline & Drought & Normal & Combined & Drought & Normal & Combined & Drought & Normal & Combined & Drought & Normal & Combined \\
\hline $\mathbf{P}_{1} \mathbf{x} \mathbf{P}_{2}$ & $-13.38 * *$ & -2.16 & $-7.62 * *$ & $-27.88^{* *}$ & $-18.24 * *$ & $-22.94 * *$ & $\mathbf{0}$ & 4 & 1.75 & $\mathbf{0}$ & $\mathbf{0}$ & $\overline{\mathbf{0}}$ \\
\hline $\mathbf{P}_{1} \mathbf{x} \mathbf{P}_{3}$ & $-13.15 * *$ & 1.88 & $-5.27 *$ & $-19.73 * *$ & $-9.34 * *$ & $-14.19 * *$ & $\mathbf{0}$ & $-11.11 *$ & -5.08 & 0 & -20 & -9.68 \\
\hline $\mathbf{P}_{1} \mathbf{x} \mathbf{P}_{4}$ & $-27.74 * *$ & $3.79 * *$ & $-11.34 * *$ & $-33.11 * *$ & $-6.39 * *$ & $-19.03 * *$ & -6.25 & $12 *$ & 1.75 & -6.25 & 7.69 & $\mathbf{0}$ \\
\hline $\mathbf{P}_{1} \mathbf{x} \mathbf{P}_{5}$ & $40.09 * *$ & $47.35 * *$ & $43.82 * *$ & -0.54 & $5.36 *$ & 2.48 & -3.03 & -7.14 & -4.92 & -5.88 & -18.75 & -12.12 \\
\hline $\mathbf{P}_{1} \mathbf{X P}_{6}$ & 7.52 & $11.9 * *$ & $9.96 * *$ & $-13.96 * *$ & $6.88 * *$ & -3.28 & $10.34 *$ & $25 * *$ & $16.98 * *$ & 0 & 25 & 10.71 \\
\hline $\mathbf{P}_{2} \mathbf{x} \mathbf{P}_{3}$ & $10.19 * *$ & $4.62 * *$ & $7.25 * *$ & $-13.81 * *$ & $-20.31 * *$ & $-17.28 * *$ & 0 & $-14.29 * *$ & -6.67 & 0 & -20 & -9.68 \\
\hline $\mathbf{P}_{2} \times P_{4}$ & -3.74 & $-4.45 * *$ & -4.11 & $-24.61^{* *}$ & $-26.45 * *$ & $-25.58 * *$ & $-25 * *$ & -7.69 & $-17.24 * *$ & $-25^{*}$ & -7.69 & -17.24 \\
\hline $\mathbf{P}_{2} \times P_{5}$ & $107.89 * *$ & $105.83 * *$ & $106.82 * *$ & $69.54 * *$ & $68.85 * *$ & $69.19 * *$ & $-27.27 * *$ & $-24.14 * *$ & $-25.81 * *$ & $-29.41 * *$ & $-31.25 * *$ & $-30.3 * *$ \\
\hline $\mathbf{P}_{2} \times P_{6}$ & 43.01** & $55.27 * *$ & $49.97 * *$ & $36.04 * *$ & 34.88** & $40.99 * *$ & -3.45 & -4 & -3.7 & -12.5 & -7.69 & -10.34 \\
\hline $\mathbf{P}_{3} \times \mathbf{P}_{4}$ & -3.04 & $-4.09 * *$ & -3.6 & -3.21 & $-5.53 * *$ & $-4.45^{*}$ & 6.25 & -1.79 & 2.5 & 6.25 & -8.33 & -0.81 \\
\hline $\mathbf{P}_{3} \times P_{5}$ & $80.4^{* *}$ & $61.06 * *$ & $70.16 * *$ & $22.33 * *$ & $7.54 * *$ & $14.44 * *$ & -3.03 & -3.23 & -3.13 & -5.88 & -6.25 & -6.06 \\
\hline $\mathbf{P}_{3 \times P_{6}}$ & $29.45 * *$ & $17.63 * *$ & $22.78 * *$ & -2.31 & 0.57 & -0.77 & $37.93 * *$ & $18.52 * *$ & $28.57 * *$ & $25^{*}$ & 6.67 & 16.13 \\
\hline $\mathbf{P}_{4} \times P_{5}$ & $-26.64 * *$ & $12.93 * *$ & $-5.88 *$ & $-50.21 * *$ & $-24.01 * *$ & $-36.41 * *$ & $-9.09 *$ & $-37.93 * *$ & $-22.58 * *$ & -11.76 & $-43.75 * *$ & $-27.27 *$ \\
\hline $\mathbf{P}_{4} \times P_{6}$ & $-28.75 * *$ & $-21.73 * *$ & $-24.82 * *$ & $-46.17 * *$ & $-32.22 * *$ & $-38.82 * *$ & $10.34 *$ & 4 & 7.41 & 0 & 0 & 0 \\
\hline $\mathbf{P}_{5 \times P_{6}}$ & 0.24 & $-12.56 * *$ & -7.18 & $-14.83 * *$ & $-35.63 * *$ & $-27.61 * *$ & $40 * *$ & -7.14 & $17.24 * *$ & 23.53* & -18.75 & 3.03 \\
\hline
\end{tabular}

$*$ and $* *$ significant at 0.05 and 0.01 levels of probability, respectively. 
Table 7. Heterosis relative to mid parent and better parent for total sugars and polyphenol contents under normal irrigation (N) and drought stress (D) as well as the combined over them $(\mathrm{C})$

\begin{tabular}{|c|c|c|c|c|c|c|c|c|c|c|c|c|}
\hline \multirow[b]{2}{*}{ Cross } & \multicolumn{6}{|c|}{ Total sugars } & \multicolumn{6}{|c|}{ Total polyphenol } \\
\hline & \multicolumn{3}{|c|}{ Mid Parent (M.P) } & \multicolumn{3}{|c|}{ Better Parent ( B.P) } & \multicolumn{3}{|c|}{ Mid Parent (M.P) } & \multicolumn{3}{|c|}{ Better Parent ( B.P) } \\
\hline $\mathbf{P}_{1} \mathbf{x} \mathbf{P}_{2}$ & $\begin{array}{l}\text { Drought } \\
-30.82 * *\end{array}$ & $\begin{array}{r}\text { Normal } \\
-14.09 * *\end{array}$ & $\begin{array}{l}\text { Combined } \\
-23.65 * *\end{array}$ & $\begin{array}{l}\text { Drought } \\
-38.2 * *\end{array}$ & $\begin{array}{l}\text { Normal } \\
-23.01\end{array}$ & $\begin{array}{l}\text { Combined } \\
-31.7 *\end{array}$ & $\begin{array}{l}\text { Drought } \\
39.56 * *\end{array}$ & $\begin{array}{l}\text { Normal } \\
6.23 * *\end{array}$ & $\begin{array}{l}\text { Combined } \\
26^{* *}\end{array}$ & $\begin{array}{l}\text { Drought } \\
39.38 * *\end{array}$ & $\begin{array}{r}\text { Normal } \\
-14.95 * *\end{array}$ & $\begin{array}{l}\text { Combined } \\
14.32 * *\end{array}$ \\
\hline $\mathbf{P}_{1} \mathbf{x} \mathbf{P}_{3}$ & $\mathbf{0}$ & $-47.83 * *$ & $-21.36 * *$ & -8.43 & $-48.42 * *$ & -25.53 & $-39.09 * *$ & $-40.8 * *$ & $-39.87 * *$ & $-43.29 * *$ & $-45.9 * *$ & $-44.49 * *$ \\
\hline $\mathbf{P}_{1} \mathbf{P P}_{4}$ & 1.25 & $-25.35 * *$ & $-10.68 * *$ & -8.99 & -26.92 & -16.66 & $-15.19 * *$ & $15.69 * *$ & $-2.59 * *$ & $-20.82 * *$ & 0.31 & $-4.55 *$ \\
\hline $\mathbf{P}_{1} \times P_{5}$ & $-22.05 * *$ & $-17.07 * *$ & $-19.93 * *$ & -27.3 & -23.31 & -25.59 & $44.26 * *$ & $-19.1 * *$ & $17.3 * *$ & $22.84 * *$ & $-40.39 * *$ & $-6.32 * *$ \\
\hline $\mathbf{P}_{1} \mathbf{X P}_{6}$ & 2.7 & -6.42 & -1.37 & -18.65 & -20 & -19.23 & $4.63 * *$ & $23.12 * *$ & $12.64 * *$ & $4.53 * *$ & $9.76 * *$ & $6.94 * *$ \\
\hline $\mathbf{P}_{2} \times P_{3}$ & -7.22 & $-9.94 * *$ & $-8.44 *$ & -9.73 & -18.46 & -13.81 & $7.46^{* *}$ & $13.81 * *$ & $9.98 * *$ & 0.18 & -1.76 & $7.92 * *$ \\
\hline $\mathbf{P}_{2} \times P_{4}$ & 8.09 & $8.25 *$ & 8.16 & 7.32 & -1.1 & 3.34 & $-34.35 * *$ & $22.86 * *$ & $-14.49 * *$ & $-38.78 * *$ & $11.74 * *$ & $-20.96 * *$ \\
\hline $\mathbf{P}_{2} \times P_{5}$ & $11.02 *$ & -2.01 & 5.46 & 5.97 & -5.31 & 1.2 & $16.57 * *$ & $72.17 * *$ & $36.09 * *$ & -0.62 & $53.89 * *$ & $17.93^{* *}$ \\
\hline $\mathbf{P}_{2} \times P_{6}$ & $21.48 * *$ & -6.91 & 8.7 & 5.86 & -11.76 & -1.71 & $-20.71 * *$ & $23.18 * *$ & $-4.36 * *$ & $-20.75 * *$ & $8.89 * *$ & $\mathbf{- 8 . 8 4} * *$ \\
\hline $\mathbf{P}_{3} \times P_{4}$ & $-37.72 * *$ & $-39.2 * *$ & $-38.42 * *$ & $-38.99 *$ & $-39.81 *$ & $-39.37 *$ & $-10.37 * *$ & $6.42 * *$ & $-3.67 * *$ & $-21.67 * *$ & 0.41 & $-9.37 * *$ \\
\hline $\mathbf{P}_{3} \times P_{5}$ & $-53.11 * *$ & $-49.79 * *$ & $-51.63 * *$ & $-54.03 * *$ & $-53.08 * *$ & $-52.59 * *$ & $37.76 * *$ & $78.93 * *$ & $54.88 * *$ & $25.05 * *$ & $40.65 * *$ & $32.09 * *$ \\
\hline $\mathbf{P}_{3} \times P_{6}$ & $-40.48 * *$ & $-38.32 * *$ & $-39.46 * *$ & $-49.32 * *$ & $-46.77 *$ & $-48.13 * *$ & $4.06 * *$ & 0.06 & $2.36 * *$ & -3.03 & -2.63 & -0.64 \\
\hline $\mathbf{P}_{4} \times P_{5}$ & -5.95 & $-8.82 * *$ & -7.23 & -9.61 & -13.97 & -7.65 & $3.83 * *$ & $82.63 * *$ & $32.02 * *$ & $-16.42 * *$ & $50.21 * *$ & $7.09 * *$ \\
\hline $\mathbf{P}_{4} \times P_{6}$ & $13.33^{*}$ & $13.62 * *$ & $13.47 * *$ & -1.83 & -1.1 & -1.48 & $-44.96^{* *}$ & $-28.27 * *$ & $-38.68 * *$ & $-48.65^{* *}$ & $-30.5 * *$ & $-40.62 * *$ \\
\hline $\mathrm{P}_{5 \times P_{6}}$ & $54.73 * *$ & 4.53 & $32.36^{* * *}$ & 29.61 & -4.07 & 15.36 & $6.9 * *$ & $7.44 * *$ & $7.11 * *$ & $-8.9 * *$ & $-13.79 * *$ & $-10.87 * *$ \\
\hline
\end{tabular}


Where, the most desirable mid parent heterosis effects were detected for the crosses $\mathrm{P}_{5} \times \mathrm{P}_{6}$ (54.73), $\mathrm{P}_{4} \times \mathrm{P}_{6}$ (13.62), and $\mathrm{P}_{5} \times \mathrm{P}_{6}$ (32.36) in drought stress, normal irrigation and combined analysis, respectively. However, none of the crosses expressed significant and positive heterotic effects relative to mid parent in all environments.

For total polyphenol, 9, 11 and 9 crosses expressed highly significant and positive heterotic effects relative to mid parent in drought stress, normal irrigation and combined data, respectively. The respective crosses for better parent heterosis were 4, 5 and 6 (Table, 7). The most desirable mid parent heterosis effects were detected for the crosses $\mathrm{P}_{1} \times \mathrm{P}_{5}$ (44.26), $\mathrm{P}_{4} \times \mathrm{P}_{5}$ (82.63), and $\mathrm{P}_{3} \times \mathrm{P}_{5}$ (54.88) in drought stress, normal irrigation and combined analysis, respectively. While, the most desirable heterotic effects relative to better parent were detected for the crosses $\mathrm{P}_{1} \times \mathrm{P}_{2}$ in drought condition, $\mathrm{P}_{2} \times \mathrm{P}_{5}$ in normal irrigation; and $\mathrm{P}_{3} \times \mathrm{P}_{5}$ in the combined analysis being 39.38, 53.89 and 32.09, respectively (Table, 7).

\section{References}

A.O.A.C. 1990. Official Methods of analysis of the Association Official Analytical Chemists. $15^{\text {th }}$ ed. Published by the Association of Official Analytical Chemists, Inc. Anlington, Virginia 22201, U.S.A.

Abdel-Mageed, A.H.A. and N. Gruda. 2009. Performance of different tomato genotype in the arid tropics of Sudan during the summer season. J. Agric. and Rural Development in the Tropics and subtropics, 2:147-154.

Adhi, S.; R.V.S.K. Reddy; M. Sujatha and M. Pratap. 2014. Gene action and combining ability analysis for yield and quality improvement in tomato (Solanum Lycopersicon L.). Plant Archives, 14(1): 307-311.

Ahmed, S.; A.M.K., Q. Uamruzzaman and M.R. Islam. 2011. Estimate of heterosis in tomato (Solanum lycopersicum L.). Bangl. J. agric. Res. 36:521-527.

Aksic.M; S. Gudzic; N. Deletic; N. Gudzic and S.Stojkovic.2011 Tomato fruit yield and evapotranspiration in the conditions of south Serbia. Bulgariane .J.Agric., 17(2):150-157.

Alam, M.S.; S. Ahmad; M.M. Hossain and A.K.M.A. Islam. 2010. Performance of heat tolerant tomato hybrid lines under hot, humid conditions. Bangladesh J. Agric. Res., 35: $367-$ 373.

Anita, P.; R. V. S. K. Reddy; J. D. Babu; S. S. Kumar and N. Sunil. 2013. Combining ability analysis for yield and physiological drought related traits in tomato (Solanum lycopersicum 1.) under moistures stress. The Bioscan, 8(4): 15371544.
Aref and A. Abdul-Baki. 1991. Tolerance of tomato cultivars and selected germplasm to heat stress. J. Amer. Soc. Hort. Sci., 116 (6):1113-1116.

Bhnan, E.Y. 2002. Genetics studies on tomato. Ph. D. Thesis, Fac. Agric. Cairo Univ.

Birhanu. K; K. Tilahun. 2010. Fruit yield and quality of drip-irrigated tomato under deficit irrigation Ajfand online.,10 (2):2139-2151.

Borgohain, R. and A. Swargiary. 2008. Evaluation of tomato genotypes for high temperature tolerance. Indian .J . Plant. Gen. Reso. 21 (1): 9394.

Chattopadhyay, A.; V.D., Shende; T. Seth and S. Mukherjee. 2012. Breeding tomato (Solanum lycopersicum $\mathrm{L}$.) for higher productivity and better processing qualities. SABRAO J. Breed. Genet. 44:302-321.

Cochran, W.G. and G.M. Cox. 1957. Experimental Design, $2^{\text {nd }}$ ed. John Wiley, N.Y. USA.611p.

Dhaliwal, M.S.; S. Singh; and D.S. Cheema. 2003. Line $\mathrm{x}$ tester analysis for yield and processing attributes in tomato. J. Res. 40(1): 49-53.

Dissanayaka , D.M.; H.F. Hemal; H.M. Welegama and H.M. Herath. 2014. Diallel analysis of parental lines for the development of tomato (Solanum lycopersicum L.) $\mathrm{F}_{1}$ hybrids. 6th Annual Research Symposium.

Dissanayaka , D.M.; H.F. Hemal; H.M. Welegama and H.M. Herath. 2014. Diallel analysis of parental lines for the development of tomato (Solanum lycopersicum L.) $\mathrm{F}_{1}$ hybrids. 6th Annual Research Symposium.

Droka, D.; R. Kumar; S. Joshi and R.K. Yadav. 2013. Genetic studies of quality traits in tomato (Solanum lycopersicum L) under low temperature. Vegetable Sci., 39(2): 189-191.

Farshadfar, E.; S. Mahjouri and M. Aghaee. 2008. Detection of epistasis and estimation of additive and dominance components of genetic variation for drought tolerance in durum wheat. J Biol Sci 8(3): 548-603.

Flood, A.E. and C.A. Priestly. 1973. Two improved methods for the determination of total sugars. J.Sci. Fd, Agric, 24:953.

Gaikwad, S. P.; S. B. Raijadhav; A. D. Dumbre and T. J. Bhor. 2002. Combining ability analysis in tomato by use of line $\mathrm{x}$ tester technique. $\mathrm{J}$. Maharashtra Agric. Univ., 27(3): 308-310.

Gul, R.; H.U. Rahman; LH. Khalil; S.M.A. shall and A. Ghafoor. 2010. Heterosis for flower and fruit traits in tomato (Lycopersicon esculentum). African J. Biotechnology, 9(27): 4144-4151.

Harmanto, V.M; M.S. Salokhe and H.J. Tantau. 2005. Water requirement of drip irrigated tomatoes grown in greenhouse in tropical environment. Agric. water management 71: 225242.

Ibrahim.A.A.2005. physiological studies on yield and quality of tomato Ph.D. Thesis, Fac. Agric., Benha University, Egypt, PP124. 
Joshi, A. and M.C. Thakur .2003. Exploitation of heterosis for yield and yield contributing traits in tomato. Prog. Hort., 35(1): 64-68.

Kumar, R.; K. Srivastava; N.P. Singh; N.K. Vasistha; R.K. Singh and M.K. Singh. 2013. Combining Ability Analysis for Yield and Quality Traits in Tomato (Solanum lycopersicum L). J. Agric. Sci., 5 (2): 213-218.

Kumar, S. and M. Singh. 2016. Growth, fruit yield and quality of tomato (Lycopersicon esculentum Mill.) as affected by deficit irrigation regulated on phenological basis Agricultural Water Management Volume 171, Pages 73-79.

Marbhal, S.K.; A.S. Ranpise and D.B. Kshirsagar. 2016. Heterosis study in cherry tomato for quantitative traits. Inter. Res. J. Multidisciplinary Studies, 2 (2): 2454-8499.

Mehboob, A.; G. Zishan; U.K. Zaheer; K. Bilal; S. Maria; U. Ihsan. 2015. Study of heterosis in different cross combinations of tomato for yield and yield components. Inter. J. Biosciences, 7 (2): 12-18.

Nouri, A.; A. Etminan; J. A. Teixeira da Silva and R. Mohammadi. 2011. Assessment of yield, yield related traits and drought tolerance of durum wheat genotypes (Triticum turjidum var. durum Desf.). Aust J Crop Sci 5(1): 8-16.

Olanike. A and C. Madramootoo. 2014. Response of greenhouse- grown bell pepper (Capsicum annuиm L.) to variable irrigation. Canadian J. plant sci.,94 (2) :303- 310.

Panigrahi. B; D.P. Roy and S.N. panda. 2010. Water use and yield response of tomato as influenced by drip and furrow irrigation .Int. Agric. Engineering J., 19..(1)19-30.

Paschal, H.E.H. and J. R. Wilcox. 1975. Heterosis and combining ability in exotic soy bean germplasm. Crop Sci., 13:344-349.

Rahmani, G.; R. Hidayat; H. K. Iftikhar; M. A. Syed and S.h. Abdulghafoor. 2010. Heterosis for flower and Huit traits intomato (Lycopersicon esculentum Mill). Air. Jor. Bio., 9(27):4144-4151.
Rehman, F.; S. Khan; Faridullah and Shafiullah. 2000. Performance of different tomato cultivars under the climatic conditions of northern areas (Gilgit). Pakistan J. Biological Sci., 3 (5): 833835.000

Sacco, A.; B. Greco; A. D. Matteo; R.D. Stefano and A. Barone. 2013. Evaluation of tomato genetic resources for response to water deficit. American J. Plant Sci., 4: 131-145.

Shakil, Q.; M. Saleem; A.A. Khan and R. Ahmad. 2017. Genetic analysis for the determination of heterosis and combining ability of tomato fruit morphological traits under frost stress. Pakistan J. of Agric. Sci. 54(2):383-393.

Sibomana.I. C; J.N. Aguyoh and A.M. Opiyo. 2013. Water stress affects growth and yield of container grown tomato (lycopersicon esculentum mill) plants. G.J.B.B., 2(4):461- 466.

Singh, A.K.; R.S. Pan and M. Rai. 2007. Heterosis for fruit yield and its components in tomato (Solanum Iycopersicon L) Veg. Sci., 34(1):108.

Singh, P. and M. Kumar. 2017. Antagonistic actinomycetes mediated resistance in solanum lycopersicon mill. against rhizoctonia solanikühn. National Academy of Sciences, 87(3): 789-798.

Solieman, T.H.I.; M.A. H. EL-Gabry and A. I. Abido. 2013. Heterosis, potence ratio and correlation of some important characters in tomato (Solanum lycopersicum L.). Sci. Hort., 150, 25 30.

Souza, LM.; M.E.G.Z. Paternian; P.C.T. Melo and A.M.T. Melo. 2012. Diallel cross among fresh market tomato inbreeding lines. Hortie.Bras., 30(2):246-251.

Tiwari, A. and G. Lal. 2004. Studies on heterosis for qualitative and quantitative characters in tomato. Prog. Hort., 36(1): 122-127.

Wahb-Allah, M. A.; A.A. Alsadon and A. A. Ibrahim. 2011. Drought tolerance of several tomato genotypes under greenhouse conditions. World Appl. Sci. J., 15 (7): 933-940. 